\title{
Theoretical study of ice cover phenology at large freshwater lakes based on SMOS MIRAS data
}

\author{
Vasiliy Tikhonov $^{1,2}$, Ilya Khvostov ${ }^{3}$, Andrey Romanov ${ }^{3}$, and Evgeniy Sharkov ${ }^{1}$ \\ ${ }^{1}$ Department of Earth Research from Space, Space Research Institute of the Russian Academy of Sciences, \\ 84/32 Profsoyuznaya Str., Moscow 117997, Russia \\ ${ }^{2}$ Moscow Institute of Physics and Technology (State University), 9 Institutskiy Per., Dolgoprudny, \\ Moscow Region 141701, Russia \\ ${ }^{3}$ Institute for Water and Environmental Problems, Siberian Branch of the Russian Academy of Sciences, \\ 1 Molodezhnaya Str., Barnaul 656038, Altai Krai, Russia
}

Correspondence: Vasiliy Tikhonov (vtikhonov@asp.iki.rssi.ru)

Received: 31 January 2018 - Discussion started: 8 February 2018

Revised: 13 July 2018 - Accepted: 18 July 2018 - Published: 23 August 2018

\begin{abstract}
The paper presents a theoretical analysis of seasonal brightness temperature variations at a number of large freshwater lakes: Baikal, Ladoga, Great Bear Lake (GBL), Great Slave Lake (GSL), and Huron, retrieved from Microwave Imaging Radiometer with Aperture Synthesis (MIRAS) data $(1.4 \mathrm{GHz})$ of the Soil Moisture and Ocean Salinity (SMOS) satellite. The analysis was performed using the model of microwave radiation of plane layered heterogeneous nonisothermal medium. The input parameters for the model were real regional climatological characteristics and glaciological parameters of ice cover of the study lakes. Three distinct seasonal brightness temperature time regions corresponding to different phenological phases of the lake surfaces: complete ice cover, ice melt and deterioration, and open water were revealed. The paper demonstrates the possibility to determine the beginning of ice cover deterioration from satellite microwave radiometry data. The obtained results can be useful for setting the operating terms of winter crossings and roads on ice, as with the beginning of ice deterioration, these transportation routes across water bodies (rivers, lakes, water reservoirs) become insecure and cannot be used any more.
\end{abstract}

\section{Introduction}

Satellite microwave radiometry is widely employed in studies of the Earth's cryosphere (Tedesco, 2015). The data are used to retrieve sea ice concentration and thickness in polar regions (Tian-Kunze et al., 2014; Tikhonov et al., 2016; Ricker et al., 2017), investigate glacial depths of Greenland and Antarctica (Zwally and Giovinetto, 1995; Magand et al., 2008), analyze ice cover characteristics (Dietz et al., 2012; Lemmetyinen, 2012), detect permafrost zones and estimate depth of soil freezing (Zuerndorfer et al., 1990). They are also used to assess the depth and phenology of ice cover of large freshwater lakes (Kang et al., 2010, 2012, 2014; Kang, 2012; Kontu et al., 2014; Du et al., 2017).

Kang et al. (2010, 2012, 2014) analyzed seasonal variations of brightness temperature at GBL and GSL derived from AMSR-E (Advanced Microwave Scanning Radiometer for EOS) data. They demonstrated that the $18.7 \mathrm{GHz}$ $\mathrm{H}$-pol channel was the most sensitive to the phenology of ice cover. The channel data allow determining the dates of ice cover freeze-onset-melt-onset and ice-on-ice-off (Kang et al., 2010, 2012; Kang, 2012). It was found in Kang et al. (2010, 2014) and Kang (2012) that at $18.7 \mathrm{GHz}$ V-pol, brightness temperature greatly depends on ice thickness. The results obtained in these works enabled the authors to develop an algorithm for the determination of phenology phases of lake ice cover from 18.7 GHz H-pol (Kang, 2012; Kang et al., 2012) data, as well as calculate simple regression 
dependencies of ice thickness on $18.7 \mathrm{GHz} \mathrm{V}$-pol brightness temperature (Kang, 2012; Kang et al., 2014) for GBL and GSL.

Du et al. (2017) presented a novel automatic algorithm for daily analysis of ice condition of the lakes of the Northern Hemisphere. The data used are AMSR-E and AMSR2, channel $36.5 \mathrm{GHz}$, H-pol.

However, neither AMSR-E, nor the newer AMSR2 encompasses all the possibilities of satellite microwave radiometry. Their lowest frequency channel is $6.9 \mathrm{GHz} \mathrm{H}$ - and $\mathrm{V}$-pol (Tikhonov et al., 2016). Even at this frequency, the penetration depth in wet snow and ice is only a few centimeters or less (Tikhonov et al., 2013, 2014). So, during the melt period, AMSR receives radiation formed only by the thin upper layer of the medium (snow or ice) and no signal from deeper layers (ice cover). Besides, the lower layer of ice cover in direct contact with water is always wet. This also entails the loss of information on the characteristics of deep ice layers and inadequate interpretation of satellite data even in winter (cold) period.

The MIRAS instrument on board the SMOS satellite operates at $1.4 \mathrm{GHz}$ (Kerr et al., 2010). At this frequency, the electromagnetic penetration depth is considerably greater (Tikhonov et al., 2013, 2014) and, in contrast to AMSR, the radiation emitted from deeper layers of snow and ice cover can be received. In recent years, a considerable number of publications have appeared regarding studies of various Earth covers in L-band. Among them are works on brightness temperature variations of the Antarctica ice sheet (Macelloni et al., 2013, 2014); analysis of snow cover brightness temperature dependencies on snow wetness and density and ground permittivity (Naderpour et al., 2017; Schwank et al., 2015; Schwank and Naderpour, 2018a, b); snow thickness retrieval over thick Arctic sea ice (Maaß et al., 2013); brightness temperature variations of Arctic sea ice (Heygster et al., 2009; Richter et al., 2018); retrieval of Arctic sea ice thickness (Huntemann et al., 2014; Kaleschke et al., 2012, 2016; Ricker et al., 2017; Tian-Kunze et al., 2014; Zhou et al., 2018).

Various models of radiative and dielectric properties of layered media (snow cover, sea and lake ice, ice sheet, etc.) are employed to interpret data obtained by satellite microwave radiometers (see, for example, Heygster et al., 2009). The most widely used are HUT model (Helsinki University of Technology; Pulliainen et al., 1999; Lemmetyinen et al., 2010) and MEMLS (Microwave Emission Model of Layered Snowpacks; Mätzler and Wiesmann, 1999; Wiesmann and Mätzler, 1999). HUT model was successfully used to analyze brightness temperature of snow- and icecovered lakes and wetlands derived from aerial and satellite microwave radiometry data (Gunn et al., 2011; Kontu et al., 2014). Modified versions of MEMLS were used for detailed analysis of L-band emission of freezing ground covered in snow as well as wet snow cover (Schwank et al., 2014, 2015; Schwank and Naderpour, 2018a, b).
Table 1. Study lakes: locations, center coordinates of examined SMOS L1C grid cells.

\begin{tabular}{llll}
\hline Lake Name & Region & Latitude & Longitude \\
\hline Baikal & Southern Siberia, Russia & $54.17^{\circ} \mathrm{N}$ & $108.91^{\circ} \mathrm{E}$ \\
Ladoga & Northwestern Russia & $60.88^{\circ} \mathrm{N}$ & $31.37^{\circ} \mathrm{E}$ \\
Huron & Great Lakes of North America & $44.56^{\circ} \mathrm{N}$ & $82.41^{\circ} \mathrm{W}$ \\
Great Slave & Northwest Territories of Canada & $61.28^{\circ} \mathrm{N}$ & $114.80^{\circ} \mathrm{W}$ \\
Great Bear & Northwest Territories of Canada & $65.97^{\circ} \mathrm{N}$ & $120.57^{\circ} \mathrm{W}$ \\
\hline
\end{tabular}

The paper presents a theoretical analysis of seasonal variations of ice cover of a number of freshwater lakes based on MIRAS L-band data. We use the model of thermal emission of multi-layered non-isothermal media (Sharkov, 2003). The dielectric properties of each layer are calculated by a quasiwave model of effective dielectric constant of a multi-phase dispersed medium (Boyarskii et al., 1994, 2002). Both models were found effective for the retrieval of brightness temperature of sea ice (Tikhonov et al., 2013, 2014), snow-firn layers of Antarctica (Tikhonov et al., 2017), and snow cover (Tikhonov et al., 2008). Here, the former model is modified for freshwater lakes. Using L-band allows receiving thermal emission from deeper ice layers in contrast to high frequency channels of SSM/I, SSMIS, AMSR-E and AMSR2. Its analysis provides information on structural and physical changes practically along the whole column of snow cover and lake ice.

\section{Data description}

Five large freshwater lakes located in different regions of the world were selected for the study. They are lakes Baikal and Ladoga situated in different climatic zones of Russia, GBL, and GSL in the northeast of Canada, and Huron, one of the Great Lakes of North America (Table 1).

\subsection{Satellite data}

To determine surface brightness temperature at $5 \mathrm{~K}$ accuracy, the SMOS L1C v620 product (Gutierrez et al., 2014) was used. L1C data are georeferenced to the DGG ISEA 4H9 discrete hexagonal geodesic grid (Sahr et al., 2003). The grid cells chosen for each lake are shown in Fig. 1 with all center coordinates listed in Table 1 . The cell linear size is $15 \mathrm{~km}$. L1C is produced from SMOS MIRAS data of $21 \mathrm{~cm}$ wave length (frequency $1.4 \mathrm{GHz}$ ) and resolution $\sim 35 \times 50 \mathrm{~km}$ for $\mathrm{H}$-pol and $\mathrm{V}$-pol at an angle of $42.5^{\circ}$. The cells were chosen so that the antenna pattern did not reach the coast.

\subsection{Climatic and glaciological data}

Regional climatic data of the lakes and glaciological characteristics of their ice covers were collected from a number of publications and websites. They provided multi-year air and water temperature, ice thickness, and snow on ice thick- 

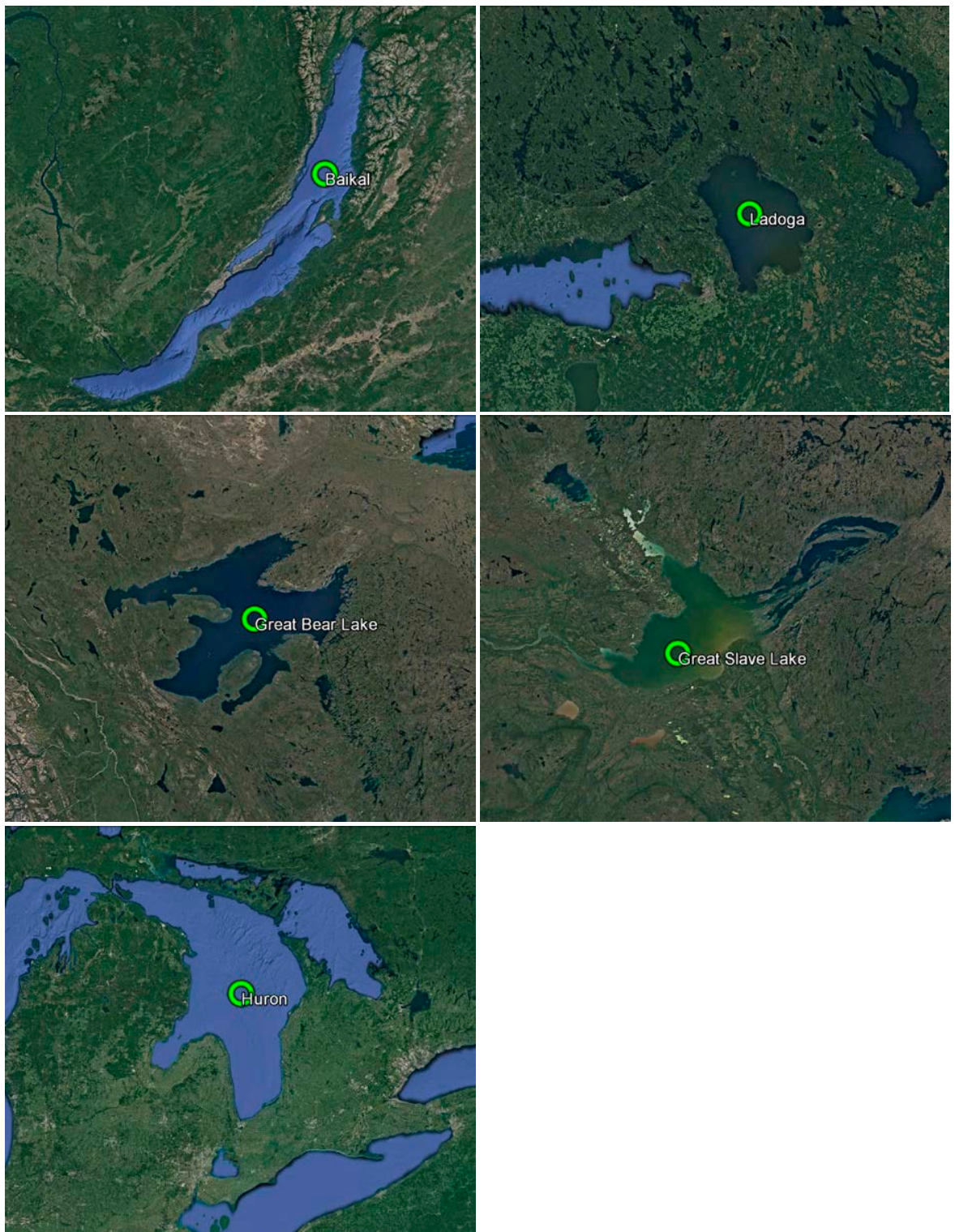

Figure 1. Maps of Baikal, Ladoga, GBL, GSL, and Huron. Green circles mark the SMOS L1C grid cells examined in the study.

ness observational data for all the study lakes. As to Baikal and Ladoga, these were Russian language works of Galaziya (1984), Tulokhonov (2008), Rumyantsev et al. (2012), Rumyantsev (2015), as well as websites of the Institute of Lake Science of the Russian Academy of Sciences (http: //www.limno.org.ru/win/rlake.php, last access: 17 August 2018) and the Climatic Reference Book of the Settlements of Russia (http://atlas-yakutia.ru/weather/spravochnik/temp/ climate_sprav-temp_3043201321.php, last access: $17 \mathrm{Au}$ gust 2018; http://atlas-yakutia.ru/weather/spravochnik/sndp/ climate_sprav-sndp_229120574.php, last access: $17 \mathrm{Au}$ gust 2018). For GBL and GSL, we used the data of Woo et al. (2007), Rouse et al. (2008), Kang et al. (2010, 2012, 2014), and Kang (2012), as well as websites of the Canadian Cryospheric Information Network (https://www.socc.ca/index.php/ccw/lakeice/links, last access: 17 August 2018) and Polar Data Catalogue (https://www.polardata.ca/pdcsearch/, last access: $17 \mathrm{Au}$ gust 2018), and the Government of Canada: Historical Data and Canadian Climate Normals (http://climate.weather.gc. ca/historical_data/search_historic_data_e.html, last access: 17 August 2018; and http://climate.weather.gc.ca/climate_ normals/index_e.html, last access: 17 August 2018). In case of Huron, data provided by Rumyantsev et al. (2012) and NOAA websites (https://www.glerl.noaa.gov//metdata/, last access: 17 August 2018; https://coastwatch.glerl.noaa.gov/ statistic/statistic.html, last access: 17 August 2018) were used. 


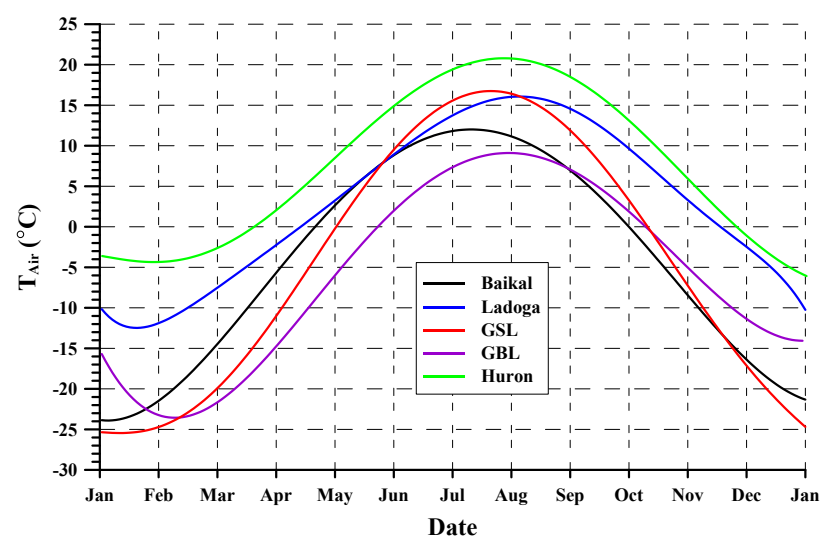

Figure 2. Seasonal variations of air temperature in the study regions.

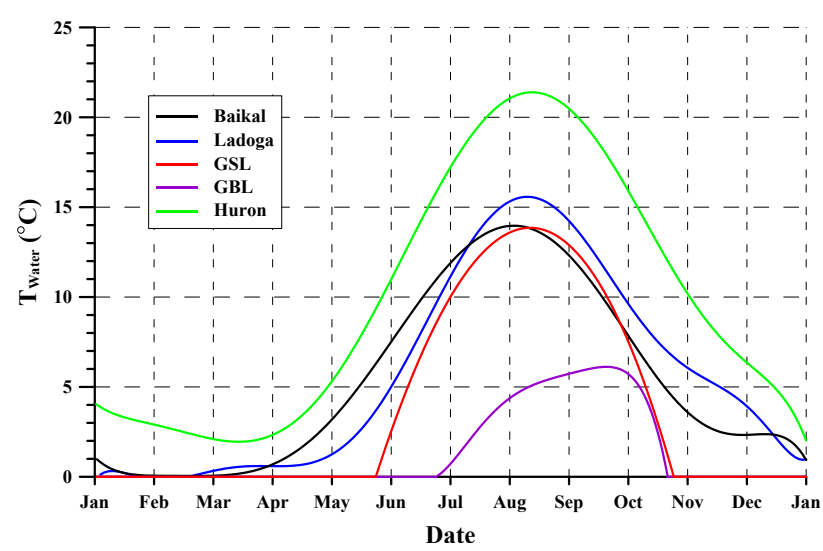

Figure 3. Seasonal variations of water surface temperature in the central parts of the study lakes.

As the lakes have considerable dimensions, we sought climatic and glaciological data sources that were geographically close to the areas of the chosen SMOS L1C grid cells. For Baikal, it is the settlement of Davsha, for Ladoga, they are Valaam Island, the town of Olonets and Pitkyaranta settlement); for GBL, the Déline settlement; for GSL, the town of Yellowknife; for Huron, Bay Island and the town of Alpena. Multi-year ground data on air and water temperature, ice and snow cover thicknesses were averaged and approximated by smooth dependencies (Figs. 2-4).

Figure 2 presents average seasonal variations of air temperature for the five study regions. It is clear from the figure, that GBL is located in the coldest region and Huron in the warmest one.

Figure 3 shows averaged seasonal variations of water surface temperature in the central part of each lake. GBL is the coldest. Even in summer, its surface water temperature does not exceed $7^{\circ} \mathrm{C}$. GBL remains free of ice for a very short period that seldom begins before the end of June. The warmest

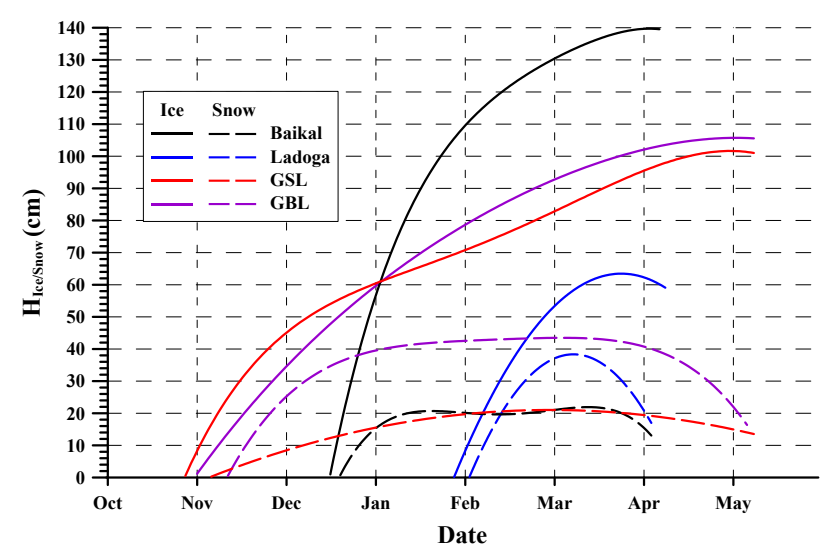

Figure 4. Seasonal variations of ice thickness up to the maximum value and thickness of snow on ice.

lake is Huron, its water surface temperature is positive nearly all the time. Huron almost never freezes up completely.

Figure 4 presents average ice thickness growth for four lakes that get completely covered by ice in the cold period of year. According to the plots, the most thick ice cover is formed on Baikal. Formation of stable ice cover begins in mid-December. Ice covers of GBL and GSL last for longer periods, starting from the end of October. On Ladoga, ice thickness is much less compared to the others and the ice cover becomes stable as late as February. On all the lakes, the thickness of snow cover above ice does not exceed $50 \mathrm{~cm}$. GBL has the thickest snow cover. A common feature for all lakes is that snow thickness decreases with the approach of warm season.

\subsection{Satellite lake data of 2012-2013}

For all lakes, 2012-2013 seasonal dependencies of brightness temperature in the selected grid cells were examined. From the analysis of these data for Baikal, Ladoga, GBL and GSL, three time regions (TRs: TR1, TR2, TR3) clearly distinct in brightness temperature characteristics were identified. For Huron, no dramatic seasonal variations of brightness temperature were recorded, its evolution fully corresponded to TR1 observed at the other four lakes (Fig. 5).

Examination of climatic and glaciological conditions of the study regions (Figs. 2-4) showed that TR1 was associated with ice-free water surface, TR2 stable ice cover, and TR3 spring evolution of lake ice.

\section{Model of microwave radiation from freshwater lake}

\subsection{The model}

A theoretical calculation was performed to interpret and analyze brightness temperature variations in the selected regions of the lakes. The model of thermal emission of multi- 
layered non-isothermal media (Sharkov, 2003; Tikhonov et al., 2014) modified for freshwater lakes was used. The model was developed on the basis of radiative transfer theory for a medium composed of flat layers taking into account multiple reflection of radiation at every layer boundary (Sharkov, 2003). Each layer was assumed to have specific physical and structural characteristics: composition, temperature, density, volumetric wetness, etc. According to the model, the radiative system consists of lake water surface covered with lake ice and then snow with a thick layer of atmosphere above (Fig. 6). For such system, brightness temperature $T_{\mathrm{Br}}$ is determined from the following relations (Sharkov, 2003; Tikhonov et al., 2014):

$$
\begin{aligned}
T_{\mathrm{Br}}^{\mathrm{v}} & =\sum_{j=1}^{2} \frac{T_{j}\left|W_{j}\right|^{2}}{\left|1-r_{j}^{-} r_{j}^{+} \exp \left(2 i \psi_{j}\right)\right|^{2}} \\
& \times\left[\left(1-\exp \left(-2 \operatorname{Im} \psi_{j}\right)\right)\left(1+\left|r_{j}^{-} \exp \left(i \psi_{j}\right)\right|^{2}\right)\right. \\
& +4 \frac{\operatorname{Im} \psi_{j}}{\operatorname{Re} \psi_{j}} \operatorname{Re}\left(r_{j}^{-} \exp \left(i \psi_{j}\right)\right) \operatorname{Im}\left(\exp \left(i \psi_{j}\right)\right) \\
& \left.\times\left(\frac{\left|k_{z_{j}}\right|^{2}-k_{x}^{2}}{\left|k_{j}\right|^{2}}\right)\right] \frac{\operatorname{Re} Z_{j}}{\operatorname{Re} Z_{0}}+T_{3}\left|W_{3}\right|^{2} \frac{\operatorname{Re} Z_{3}}{\operatorname{Re} Z_{0}}, \\
T_{\mathrm{Br}}^{\mathrm{h}} & =\sum_{j=1}^{2} \frac{T_{j}\left|W_{j}\right|^{2}}{\left|1-r_{j}^{-} r_{j}^{+} \exp \left(2 i \psi_{j}\right)\right|^{2}} \\
& \times\left[\left(1-\exp \left(-2 \operatorname{Im} \psi_{j}\right)\right)\left(1+\left|r_{j}^{-} \exp \left(i \psi_{j}\right)\right|^{2}\right)\right. \\
& \left.+4 \frac{\operatorname{Im} \psi_{j}}{\operatorname{Re} \psi_{j}} \operatorname{Re}\left(r_{j}^{-} \exp \left(i \psi_{j}\right)\right) \operatorname{Im}\left(\exp \left(i \psi_{j}\right)\right)\right] \frac{\operatorname{Re} Z_{j}}{\operatorname{Re} Z_{0}} \\
& +T_{3}\left|W_{3}\right|^{2} \frac{\operatorname{Re} Z_{3}}{\operatorname{Re} Z_{0}},
\end{aligned}
$$

where the superscripts at $T_{\mathrm{Br}}$ denote: $\mathrm{v}-\mathrm{V}-$ pol and $\mathrm{h}-\mathrm{H}-\mathrm{pol}$; subscript $j$ equal to: 0 denotes free space (atmosphere), 1 snow cover, 2 lake ice, 3 water; $k_{j}$ is wave vector in layer $j$; $T_{j}$ is physical temperature of layer $j ; r_{j}^{+}, r_{j}^{-}$are reflection coefficient at the upper and bottom boundary of layer $j$, respectively; $\psi_{j}$ is total retarding phase across layer $j ; W_{j}$ is coefficient of transmission from the inner side of the upper boundary of layer $j$ to the boundary of the layered structure (snow-atmosphere boundary in our case); $Z_{j}$ is characteristic impedance of layer $j$. The properties of each layer are defined by the following relations:

$$
\left.\begin{array}{c}
W_{j}=\prod_{m=1}^{j} \frac{Z_{m-1}^{\mathrm{in}+}+Z_{m-1}}{Z_{m-1}^{\mathrm{in}+}+Z_{m}} \exp \left(i \psi_{m-1}\right), \\
Z_{j}^{\mathrm{in}+}=Z_{j} \frac{Z_{j-1}^{\mathrm{in}+}-i Z_{j} \operatorname{tg} \psi_{j}}{Z_{j}-i Z_{j-1}^{\mathrm{in}} \operatorname{tg} \psi_{j}}, Z_{j}^{\mathrm{in}-}=Z_{j} \frac{Z_{j+1}^{\mathrm{in}-}-i Z_{j} \operatorname{tg} \psi_{j}}{Z_{j}-i Z_{j+1}^{\mathrm{in}-} \operatorname{tg} \psi_{j}}, \\
\psi_{j}=k_{z_{j}} h_{j}, k_{z_{j}}=k_{j} \cos \theta_{j}, k_{x}=k_{0} \sin \theta_{0}, \\
k_{j}=\frac{2 \pi \sqrt{\varepsilon_{j}}}{\lambda}, \cos \theta_{j}=\sqrt{\frac{\varepsilon_{j}-\varepsilon_{0} \sin ^{2} \theta_{0}}{\varepsilon_{j}},} \\
r_{j}^{+}=\frac{Z_{j-1}^{\mathrm{in}+}-Z_{j}}{Z_{j-1}^{\text {in }+}+Z_{j}}, r_{j}^{-}=\frac{Z_{j+1}^{\mathrm{in}-}-Z_{j}}{Z_{j+1}^{\text {in }-}+Z_{j}}, \\
Z_{j}=\left\{\begin{array}{l}
\frac{1}{\sqrt{\varepsilon_{j}} \cos \theta_{j}}-\text { horizontal polarization } \\
\frac{\cos \theta_{j}}{\sqrt{\varepsilon_{j}}}-\text { vertical polarization }
\end{array}\right.
\end{array}\right\},
$$

where $Z_{j}^{\text {in }+}$ is input impedance in layer $j$ at the bottom boundary for a wave propagating upward; $Z_{j}^{\text {in- }}$ is input impedance in layer $j$ at the upper boundary for a wave propagating downward; $h_{j}$ is thickness of layer $j ; \lambda$ is radiation wave length; $\theta_{0}$ is viewing angle (Fig. 6 ); $\varepsilon_{j}$ is complex dielectric constant of layer $j$. Therefore, the system radiation is determined by physical temperature and complex dielectric constant of each layer. Dielectric properties of a layer depend on its composition, temperature, wetness and other physical and structure characteristics. Besides, when the radiation wave length is comparable with the size of inhomogeneities in the medium, scattering effects should also be taken into account (Ishimaru, 1978; Bohren and Huffman, 1983). Such effects result in considerable changes in snow and ice dielectric and radiative properties (Boyarskii et al., 1994; Boyarskii and Tikhonov, 2000; Tikhonov et al., 2014). For ice and snow, such inhomogeneities can be ice grains, air pores, and water droplets.

To determine dielectric properties of lake snow and ice, the quasi-wave model of effective dielectric constant $\varepsilon_{\text {eff }}$ of a multi-phase disperse medium (QWM) was employed (Boyarskii et al., 1994, 2002). According to the model, snow cover is represented by an air medium with inclusions of spherical ice grains coated in water film and water droplets (Fig. 7a), and lake ice by a continuous freshwater ice medium with spherical inclusions of air bubbles and water droplets (Fig. 7b). The effective dielectric constant of lake snow is derived from the following equation: 

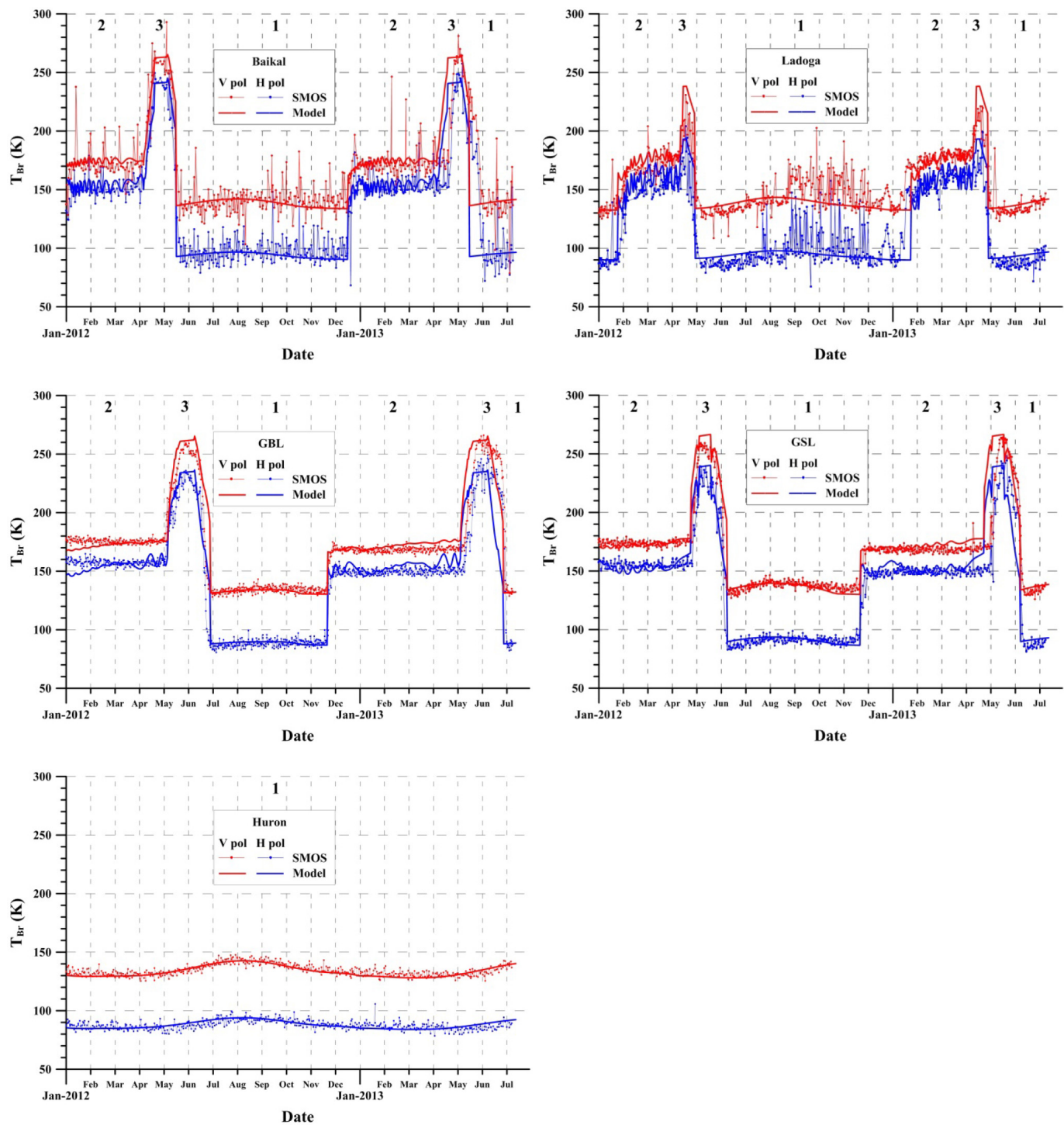

Date

Figure 5. Seasonal variations of brightness temperature within the SMOS L1C grid cells for Baikal, Ladoga, GBL, GSL, and Huron. Thin lines and symbols denote the SMOS data, thick lines represent the model results. Numbers mark brightness temperature TRs associated with open water surface (TR1); complete ice cover (TR2); and ice deterioration and melt (TR3) (see text).

$$
\begin{aligned}
& \varepsilon_{\text {eff }}^{\text {snow }} \\
& =\varepsilon_{\mathrm{a}}\left[1-\frac{4 \pi n_{\mathrm{i}}\left(\varepsilon_{\mathrm{i}}^{\mathrm{w}}+2 \varepsilon_{\mathrm{a}}\right) \frac{\left\langle f_{\omega}\right\rangle_{\mathrm{i}}}{k^{2}}}{2 \varepsilon_{\mathrm{eff}}+\varepsilon_{\mathrm{i}}^{\mathrm{W}}}-\frac{4 \pi n_{\mathrm{w}}\left(\varepsilon_{\mathrm{w}}+2 \varepsilon_{\mathrm{a}}\right) \frac{\left\langle f_{\omega}\right\rangle_{\mathrm{w}}}{k^{2}}}{2 \varepsilon_{\mathrm{eff}}+\varepsilon_{\mathrm{w}}}\right]^{-1},
\end{aligned}
$$

where $k$ is wave number; $n_{\mathrm{i}}$ and $n_{\mathrm{w}}$ are concentrations of ice grains and water droplets, respectively; $\varepsilon_{\mathrm{a}}$ and $\varepsilon_{\mathrm{w}}$ are complex dielectric constants of air and water, respectively; $\varepsilon_{\mathrm{i}}^{\mathrm{W}}$ is effective dielectric constant of an ice grain coated in water film (Boyarskii et al., 2002); $\left\langle f_{\omega}>_{\mathrm{i}}\right.$ and $\left\langle f_{\omega}>_{\mathrm{W}}\right.$ are sizeaveraged amplitudes of forward scattering on an ice grain coated in water film and a water droplet, respectively. The effective dielectric constant of lake ice is derived from

$$
\begin{aligned}
& \varepsilon_{\text {eff }}^{\text {lake ice }} \\
& \quad=\varepsilon_{\mathrm{i}}\left[1-\frac{4 \pi n_{\mathrm{a}}\left(\varepsilon_{\mathrm{a}}+2 \varepsilon_{\mathrm{i}}\right) \frac{\left\langle f_{\omega}\right\rangle_{\mathrm{a}}}{k^{2}}}{2 \varepsilon_{\text {eff }}+\varepsilon_{\mathrm{a}}}-\frac{4 \pi n_{\mathrm{w}}\left(\varepsilon_{\mathrm{w}}+2 \varepsilon_{\mathrm{i}}\right) \frac{\left\langle f_{\omega}\right\rangle_{\mathrm{w}}}{k^{2}}}{2 \varepsilon_{\text {eff }}+\varepsilon_{\mathrm{W}}}\right]^{-1},
\end{aligned}
$$

where $n_{\mathrm{a}}$ is concentration of air bubbles; $\varepsilon_{\mathrm{i}}$ is complex dielectric constant of ice; $\left\langle f_{\omega}\right\rangle_{\mathrm{a}}$ is size-averaged amplitude of forward scattering on air bubbles. The amplitudes of forward scattering $f_{\omega}$ in Eqs. (3) and (4) are calculated by the Mie theory (Bohren and Huffman, 1983). The triangle parentheses indicate averaging over the ensemble of scatterers. Sizes of the inclusions in lake ice and snow cover are assumed 


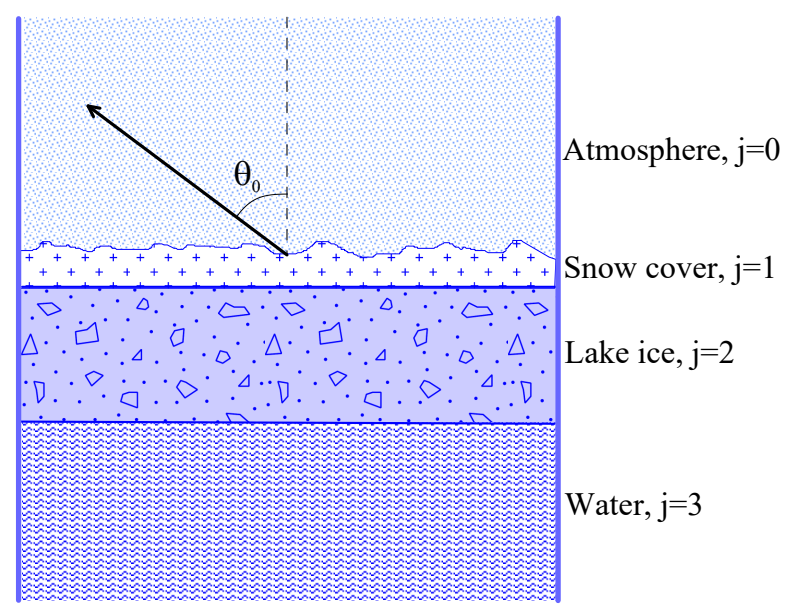

Figure 6. Model of the "water-lake ice-snow cover-atmosphere" radiating system.

to obey lognormal distribution (Colbeck, 1987). The model considers both physical and structural properties of lake ice and snow, as well as scattering effects due to structural inhomogeneities of the media. Absorption and scattering on particle inhomogeneities (spherical ice grains, air bubbles, water droplets, ice grains coated in water) are represented in Eqs. (3) and (4) by term $f_{\omega}$ which is the amplitude of forward scattering on a spherical particle. This is substantiated by the forward scattering theorem stating that the extinction cross section determining radiation losses due to wave absorption and scattering on a particle depends only on the scattering amplitude in forward direction $f_{\omega}$ (Ishimaru, 1978). Also, note that the form of the inhomogeneities in real lake snow and ice, as a rule, is not strictly spherical (Gray and Male, 1986; Voitkovskiy, 1999; Cuffey and Paterson, 2010; Singh et al., 2011). However, as shown in Bohren and Huffman, 1983, in the vicinity of the forward direction, non-spherical particles scatter radiation very similar to the way spherical ones of the same section do. So, the consideration of particle non-sphericity is not a principal issue for the model, it only complicates the calculations.

If the size of medium inhomogeneities is much less than the wavelength $(k \rightarrow 0)$, Eqs. (3) and (4) transform into the mixing formulas of Polder-van Santen model (PVSM) (Boyarskii et al., 1994). According Polder and van Santen (1946), Eqs. (3) and (4) take the following forms:

$$
\begin{aligned}
& \varepsilon_{\text {eff }}^{\text {snow }}=\varepsilon_{\mathrm{a}}\left[1-\frac{3 V_{\mathrm{i}}\left(\varepsilon_{\mathrm{i}}-\varepsilon_{\mathrm{a}}\right)}{2 \varepsilon_{\mathrm{eff}}+\varepsilon_{\mathrm{i}}}-\frac{3 V_{\mathrm{w}}\left(\varepsilon_{\mathrm{w}}-\varepsilon_{\mathrm{a}}\right)}{2 \varepsilon_{\mathrm{eff}}+\varepsilon_{\mathrm{w}}}\right]^{-1}, \\
& \varepsilon_{\text {eff }}^{\text {lake ice }}=\varepsilon_{\mathrm{i}}\left[1-\frac{3 V_{\mathrm{a}}\left(\varepsilon_{\mathrm{a}}-\varepsilon_{\mathrm{i}}\right)}{2 \varepsilon_{\mathrm{eff}}+\varepsilon_{\mathrm{a}}}-\frac{3 V_{\mathrm{w}}\left(\varepsilon_{\mathrm{w}}-\varepsilon_{\mathrm{i}}\right)}{2 \varepsilon_{\mathrm{eff}}+\varepsilon_{\mathrm{w}}}\right]^{-1},
\end{aligned}
$$

where $V_{\mathrm{i}}, V_{\mathrm{w}}$ and $V_{\mathrm{a}}$ are the volumetric parts of the mixture components: ice, water, and air.

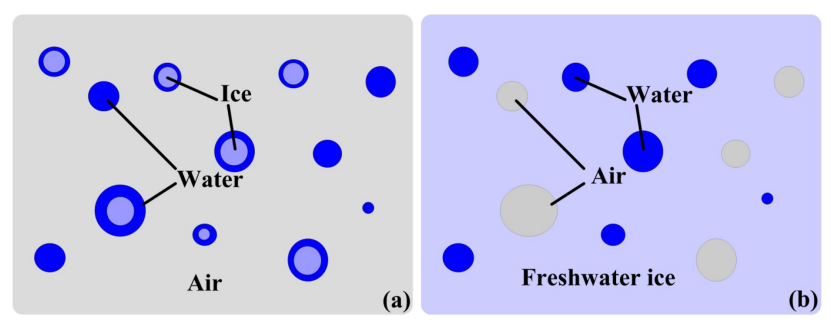

Figure 7. Models of snow cover (a) and lake ice (b).

Therefore, the complex dielectric constants $\varepsilon_{0}$ and $\varepsilon_{j}$ in Eq. (2) are defined as

$\varepsilon_{0}=1, \quad \varepsilon_{1}=\varepsilon_{\text {eff }}^{\text {snow }}, \quad \varepsilon_{2}=\varepsilon_{\text {eff }}^{\text {lake ice }}, \quad \varepsilon_{3}=\varepsilon_{\mathrm{w}}$.

Which pair of Eqs. (3) and (4) or Eqs. (5) and (6) should be used to calculate $\varepsilon_{1}$ and $\varepsilon_{2}$ depends on the ratio of the radiation wave length and the mean size of the medium (snow or lake ice) inhomogeneities.

Scattering on a rough surface was taken into account using the model described in Choudhury et al. (1979), according to which the snow-atmosphere boundary reflection coefficients are multiplied by a factor (Tikhonov et al., 2014):

$\left(\exp \left(-l \cos ^{2} \theta_{0}\right)\right)^{1 / 2}$.

The roughness parameter $l$ is defined as

$l=4 \sigma^{2}\left(\frac{2 \pi}{\lambda}\right)^{2}$,

where $\sigma$ is surface roughness standard deviation.

\subsection{Model modification}

To analyze the radiative properties of the study lakes in various seasons, snow cover and lake ice radiation penetration depth dependencies on wavelength of electromagnetic radiation were calculated using QWM and PVSM. Penetration depth is the thickness of a medium layer at which the amplitude of an electromagnetic wave penetrating the medium drops $e$ times. Penetration depth is considered to define the thickness of effectively radiating layer of the medium that can be calculated as (Sharkov, 2003; Kang, 2012)

$h_{\mathrm{PD}}=\frac{\lambda}{4 \pi \operatorname{Im}\left(\sqrt{\varepsilon_{j}}\right)}$.

Snow cover and lake ice penetration depths were determined for cold $\left(-20^{\circ} \mathrm{C}\right)$ and warm $\left(0{ }^{\circ} \mathrm{C}\right)$ conditions. At $-20^{\circ} \mathrm{C}$, snow is dry and lake ice contains minimal quantity of liquid water at its bottom in contact with lake water with temperature close to $0^{\circ} \mathrm{C}$. At $0{ }^{\circ} \mathrm{C}$, intensive melt process sets on. In this case, the maximum volumetric wetness of snow cover (volume of water contained in unit volume of snow) is determined by its density and structure and ranges $9 \%-30 \%$, but 
mostly $12 \%-15 \%$ (Kuz'min, 1957; Kotlyakov, 2000). Excess snow water trickles down to ice surface, and then leaks into cracks in ice increasing its wetness. During the melt period, wetness of lake ice is the highest and depends on its porosity, that is the volumetric fraction of cavities (pores, capillaries, cracks) that can be filled with water. To calculate the penetration depth, we used real physical parameters of lake ice and snow cover (Kuz'min, 1957; Gray and Male, 1986; Voitkovskiy, 1999; Kotlyakov, 2000; Cuffey and Paterson, 2010; Singh et al., 2011) presented in Table 2. Results of the calculations are shown in Fig. 8. Let us consider the results obtained for MIRAS (1.4 GHz). As follows from Fig. 8, the penetration depth of dry snow is of the order of $1 \mathrm{~km}$. Under negative temperatures, the penetration depth of lake ice is also large and equals several meters. Note that for both media, the calculations by QWM and PVSM are the same. The fact is explained by the negligible effects of scattering on ice grains and air bubbles at this wave frequency (Tikhonov et al., 2014). Under negative temperatures, the effective dielectric constants of snow and lake ice can be calculated by Eqs. (5) and (6). The differences in penetration depths of continuous freshwater ice and lake ice are caused by the presence of a small amount of liquid water in lake ice (Table 2) which absorbs radiation so that the penetration depth diminishes. Around $0{ }^{\circ} \mathrm{C}$, lake ice penetration depth falls significantly, to about $40 \mathrm{~cm}$ (Fig. 8). Such a dramatic change is associated with liquid water accumulating in lake ice (Table 2) and, consequently, growing radiation absorption. Here, the scattering effects are also negligible (Tikhonov et al., 2014) and Eq. (6) can be used to calculate the effective dielectric constant. However, for wet snow the effect of scattering on water droplets and ice grains coated in water is significant (Tikhonov et al., 2014). This explains the difference in penetration depths estimated by QWM and PVSM (Fig. 8). Therefore, in presence of liquid water, the effective dielectric constant of snow cover should be obtained by Eq. (3). So, given the thicknesses of snow cover and lake ice of the study lakes (Fig. 4), these media will be almost completely transparent for the $1.4 \mathrm{GHz}$ radiation under negative temperatures. At the same frequency, with the appearance of liquid water, the penetration depth of snow falls to only a few centimeters, that of lake ice a few dozens of centimeters (Fig. 8), and snow and ice covers of the lakes become non-transparent for the radiation.

Atmospheric radiation and absorption of radiation by the atmosphere were taken into account in the calculations of brightness temperature. For this purpose, a model of standard atmosphere detailed in Tikhonov et al. (2014) was used. Generally, brightness temperature $T_{\mathrm{br} \text { syst }}^{\mathrm{h}, \mathrm{v}}$ of the water surfacelake ice-snow cover-atmosphere system is determined as (Tikhonov et al., 2014)
Table 2. Properties of snow cover and lake ice taken for penetration depth calculations. Standard deviations of ice grain and air bubble sizes were assumed at $40 \%$.

\begin{tabular}{llll}
\hline & & $t=-20^{\circ} \mathrm{C}$ & $t=0{ }^{\circ} \mathrm{C}$ \\
\hline \multirow{3}{*}{ Snow cover } & dry density & $0.3 \mathrm{~g} \mathrm{~cm}^{-3}$ & $0.3 \mathrm{~g} \mathrm{~cm}^{-3}$ \\
& diameter ice grain & $0.04 \mathrm{~cm}$ & $0.06 \mathrm{~cm}$ \\
& volumetric wetness & $0 \%$ & $10 \%$ \\
\hline \multirow{3}{*}{ Lake ice } & porosity & $12 \%$ & $50 \%$ \\
& diameter air bubble & $0.1 \mathrm{~cm}$ & $0.1 \mathrm{~cm}$ \\
& volumetric wetness & $3 \%$ & $25 \%$ \\
\hline
\end{tabular}



Figure 8. Radiation penetration depth in continuous freshwater ice, snow, and lake ice calculated by the PVSM and QWM models. Lake snow and ice parameters are given in Table 2. AMSR-E and MIRAS frequencies are indicated by vertical dashed lines.

$$
\begin{aligned}
& T_{\mathrm{br} s y s t}^{\mathrm{h}, \mathrm{v}}=T_{\mathrm{Br}}^{\mathrm{h}, \mathrm{v}} \exp \left(-\xi_{\theta_{0}}\right)+T_{\mathrm{a}}+R^{\mathrm{h}, \mathrm{v}} T_{\mathrm{a}} \exp \left(-\xi_{\theta_{0}}\right) \\
& \quad+R^{\mathrm{h}, \mathrm{v}} T_{\cos } \exp \left(-2 \xi_{\theta_{0}}\right),
\end{aligned}
$$

where $T_{\mathrm{Br}}^{\mathrm{h}, \mathrm{v}}$ is calculated by Eqs. (1) and (2), either for icefree water surface or for lake ice with snow cover; $T_{\mathrm{a}}$ is brightness temperature of the atmosphere; $T_{\cos }$ is brightness temperature of cosmic radiation; $R^{\mathrm{h}, \mathrm{v}}=\left(r_{1}^{+}\right)^{2}$ is reflectivity of either water surface or lake ice with snow cover; $\xi_{\theta_{0}}$ is atmospheric absorption depending on viewing angle $\theta_{0}$. The 
determination of $T_{\mathrm{a}}, T_{\cos }$ and $\xi_{\theta_{0}}$ is detailed in Tikhonov et al. (2014).

Equations (11), (1), and (2) were used to calculate seasonal brightness temperature variations of each of the study lakes. The calculations were made for every day during the whole study period (2012-2013). Input parameters were real meteorological and glaciological data of the lakes and their regions averaged over a few decades (Figs. 2-4). The thickness of ice cannot be the same across the whole lake area, it depends on many factors (depth, underwater currents, air temperature, etc.). So, in the calculations, brightness temperature was averaged over ice depth within $\pm 10 \mathrm{~cm}$ around the mean current value (Fig. 4). The effective temperature of a lake ice layer was assumed equal to the mean of air temperature and water temperature beneath ice layer, but not higher $0{ }^{\circ} \mathrm{C}$.

It was also assumed that $\sigma$ in Eq. (9) amounted to $\sim 2 \mathrm{~cm}$ that corresponds to the mean roughness of snow cover (Rees, 2006).

In the modeling, we used mean seasonal values of snow density, ice grain diameter, volumetric wetness of snow, ice porosity and size of air bubbles in ice. These characteristics were taken from various sources (Kuz'min, 1957; Gray and Male, 1986; Kotlyakov, 2000; Kozlov, 2000; Cuffey and Paterson, 2010; Barry and Gan, 2011; Singh et al., 2011). It was assumed that in the transitional period (from TR2 to TR3), a gradual increase in lake ice porosity, as well as snow and ice wetness took place. These parameters are listed in Table 3. They were almost the same for all the lakes.

\section{Results and discussion}

Results of the calculations are presented in Fig. 5 (thick lines). From the figure, we can see that the model calculations agree well with satellite data across all five lakes. From model calculations and analysis of the results, the following features typical of TR1, TR2, and TR3 for the study lakes can be inferred.

TR1 (Fig. 5) is associated with water surface clear of ice and spans: mid May-mid December for Baikal, Maymid January for Ladoga, July-end of November for GBL, and beginning of June-end of November of GSL (Fig. 5). In TR1, brightness temperature is determined by water surface temperature and waves. From September to December, it is the season of high winds on Ladoga. Wind speed often reaches $15-25 \mathrm{~m} \mathrm{~s}^{-1}$ and waves $5-8 \mathrm{~m}$ in height. Sometimes, the water surface appears quite chaotic: waves get jumbled up with high and steep ones propagating in various directions (Rumyantsev, 2015). On Baikal, the season of high winds begins in September-October and lasts until complete freeze over. During this period, waves reach 5-6m and more in height (Galaziya, 1984; Tulokhonov, 2008). This peculiarity explains Ladoga and Baikal brightness temperature oscillations (by MIRAS data) demonstrated in Fig. 5.
On GBL and GSL, winds hardly ever exceed $10-12 \mathrm{~m} \mathrm{~s}^{-1}$ (Woo et al., 2007), which determines small amplitude oscillations of brightness temperatures (by MIRAS data) for these lakes (Fig. 5). Note that wind waves at water surface clear of ice are not taken into account in the model calculations. So, the model brightness temperature curve appears smooth as it is defined only by the temperature of water surface layer (Fig. 3). Huron almost never freezes over completely (Rumyantsev et al., 2012). In 2012-2013, it remained practically clear of ice, with the exception of the bays and coastline (see references to the NOAA website above). Therefore, TR1 spans over the whole duration of Huron observation, which is confirmed by model calculations (Fig. 5). Here, brightness temperature variations are determined by water surface temperature and waves. The latter depend on wind speed that did not exceed $10 \mathrm{~m} \mathrm{~s}^{-1}$ during the observation (see references to the NOAA website above).

TR2 brightness temperature in Fig. 5 is associated with complete ice cover. For Baikal, it lasts from mid-December to April; for Ladoga, from February to April; for GBL and GSL, from mid-November to May. In the beginning of TR2, there is a sharp rise in brightness temperature by $20-60 \mathrm{~K}$, depending on polarization and meteorological conditions. It is associated with the initiation of complete freeze over. After that, brightness temperature gradually increases by about $10 \mathrm{~K}$ as lake ice thickness grows (Kang et al., 2010, 2014). It can reach $100-140 \mathrm{~cm}$ on Baikal, $40-60 \mathrm{~cm}$ on Ladoga. 100-120 cm on GBL and GSL (Galaziya, 1984; Tulokhonov, 2008; Kang et al., 2010, 2012; Rumyantsev et al., 2012; Rumyantsev, 2015; https://www.polardata.ca/ pdcsearch/, last access: 17 August 2018). Brightness temperature oscillations (by MIRAS data) in TR2 are explained by the interference of electromagnetic waves occurring due to reflection at the upper and bottom boundaries of the ice cover. During this period, ice features low dielectric losses, because it has small quantity of pores (cracks) and little liquid water. The penetration depth at the $21 \mathrm{~cm}$ wave length is much greater than the thickness of ice (Fig. 8), so the ice cover represents an added radiative layer to the water surface. This fact is fully supported by the model calculations (Fig. 5). Presence of dry snow on ice has almost no effect on radiative properties of the lakes, because dry snow is practically radio transparent at the given frequency (1.4 GHz) (Fig. 8). Also, brightness temperature oscillations (by MIRAS data) in TR2 can be related to local temperature variations with short-lasting snow melts due to solar radiation followed by freezing.

TR3 in Fig. 5 features short-lasting abrupt rise in brightness temperature by $40-90 \mathrm{~K}$. It is the period of dramatic change in ice cover structure (intense deterioration and melt) and snow melt. Brightness temperature is affected by rapidly changing physical properties of ice: opening of numerous cracks that are filled with liquid water. This changes the dielectric properties of ice inducing strong rise in the absorption of electromagnetic radiation. Higher absorption in turn 
Table 3. Properties of snow cover, lake ice and water taken for brightness temperature modeling in TR1, TR2 and TR3. Standard deviations of ice grain and air bubble sizes were assumed at $40 \%$.

\begin{tabular}{lllll}
\hline \multicolumn{2}{l}{ Lacustrine environment } & TR1 & TR2 & TR3 \\
\hline Water & Temperature & $T_{\text {Water }}$ (Fig. 3) & $T_{\text {Water }}$ (Fig. 3) & $T_{\text {Water }}$ (Fig. 3) \\
\hline \multirow{5}{*}{ Lake ice } & Temperature & - & $\left(T_{\text {Water }}+T_{\text {Air }}\right) / 2 \leq 0$ & $0{ }^{\circ} \mathrm{C}$ \\
& Porosity & - & $10-15 \%$ & $50 \%$ \\
& Diameter air bubble & - & $0.1 \mathrm{~cm}$ & $0.1 \mathrm{~cm}$ \\
& Volumetric wetness & - & $3-8 \%$ & $25-50 \%$ \\
& Thickness & - & $H_{\text {ice }}$ (Fig. 4) & $H_{\text {ice }}$ (Fig. 4) \\
\hline \multirow{5}{*}{ Snow cover } & Temperature & - & $T_{\text {Air }}$ (Fig. 2) & $0{ }^{\circ} \mathrm{C}$ \\
& Dry density & - & $0.3 \mathrm{~g} \mathrm{~cm}^{-3}$ & $0.3 \mathrm{~g} \mathrm{~cm}^{-3}$ \\
& Diameter ice grain & - & $0.04 \mathrm{~cm}$ & $0.06 \mathrm{~cm}$ \\
& Volumetric wetness & - & $0 \%$ & $4-16 \%$ \\
& Thickness & - & $H_{\text {snow }}$ (Fig. 4) & $5-10 \mathrm{~cm}$ \\
\hline
\end{tabular}

leads to ice brightness temperature growth, as the penetration depth dramatically falls (to less than half ice thickness, Fig. 8) which results in obturation of microwave radiation from the water surface. In TR3, the snow cover is thin (5$10 \mathrm{~cm}$ ) and wet (4-16\%) (Table 3, Fig. 4). The snow cover penetration depth is not large $(\sim 20 \mathrm{~cm})$, although larger than the thickness of snow on lake ice (Table 3, Figs. 4, 8). So, the layer of wet snow has the same impact on radiation in TR3 as ice cover does in TR2. In TR3, snow cover provides additional radiation to that of melting ice. Figure 9 confirms this conclusion. The figure presents modeling results of seasonal brightness temperature variations at Baikal in 2012 for two media versions in TR2 and TR3: ice cover with and without snow layer above. Model input parameters are listed in Table 3. According to Fig. 9, in TR2 snow cover has virtually no impact on brightness temperature. The snow is dry and radio transparent at $1.4 \mathrm{GHz}$. In TR3, the main contribution to total radiation is provided by the deteriorating wet ice cover, although the contribution of snow is significant. This is linked to the appearance of liquid water and, consequently, growing effects of scattering and absorption in the snow. Note that the input of wet snow to total radiation is bigger for H-pol than it is for V-pol. TR3 lasts from the beginning of April to May at Baikal, from May to July at GBL, throughout May at GSL, and for two weeks in April at Ladoga (Fig. 5). The calendar limits of TR3 vary considerably because of varying meteorological conditions of the study lakes.

Note that the beginning of TR 1 corresponds not to the time of complete clearing of lake ice, but rather the moment when lake ice concentration gets well below $100 \%$ and snow-melt puddles appear on its surface. At $1.4 \mathrm{GHz}$, water penetration depth is $2-3 \mathrm{~cm}$ (Galakhov, 1980). So, even a thin layer of water $(\sim 3 \mathrm{~cm})$ is imaged by the radiometer quite like free water surface.

Results of the present work agree with those published by Kang (2012) and Kang et al. (2012). In these papers, the authors investigate ice cover phenology of GBL and

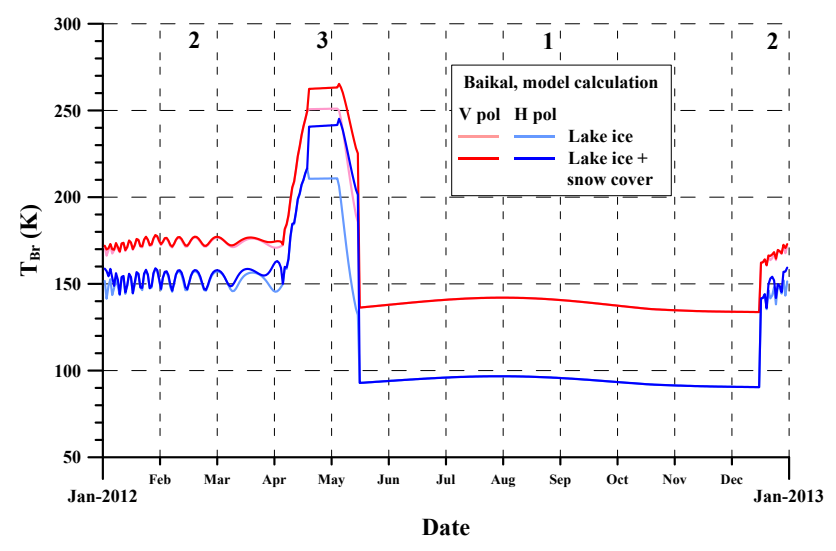

Figure 9. Model variations of brightness temperature within the SMOS L1C grid cell for Baikal. TR2 and TR3 are calculated for ice without snow (rose and blue lines) and covered by snow (red and blue lines).

GSL derived from AMSR-E data. Lake ice and snow penetration depths for AMSR-E frequencies (6.9, 18.7, 23.8, 36.5, 89.0 GHz) are much less than for MIRAS (Fig. 8). At $6.9 \mathrm{GHz}$, the penetration depth is $\sim 30 \mathrm{~cm}$ for dry lake ice and $0.5-2 \mathrm{~cm}$ for wet ice and wet snow (Fig. 8). Consequently, during the cold winter period, when almost no liquid water is present in snow and lake ice, AMSR-E receives electromagnetic radiation emitted by the upper layer $(\sim 30 \mathrm{~cm})$ of the ice cover. In warm season, when snow and lake ice become wet, AMSR-E receives radiation only from the $0.5-2 \mathrm{~cm}$ thick surface layer. Therefore, the effect of abrupt brightness temperature rise during ice cover deterioration and melt period is much less pronounced for AMSR-E than MIRAS. AMSR-E can record only snow or upper ice layer melt, as it receives radiation practically from the surface. In contrast, MIRAS, even in the warm season, receives radiation from substantially larger depths $(\sim 20-40 \mathrm{~cm})$, thus 
recording changes within the ice cover (deterioration and melt).

It is noteworthy that the above analysis of seasonal changes of brightness temperature of the lakes was based on theoretical modeling and model calculations. As input model parameters, we took mean seasonal characteristics of snow cover and lake ice (density, ice grain size, porosity, etc.) as well as multi-year averages of meteorological parameters (air and water temperature, ice and snow thickness). Such parameters as ice and snow density, ice grain and air pore size have little effect on lake ice brightness temperature due to absence of scattering and low absorption at L-band (see Sect. 3.2 and Fig. 8). However, air, snow and ice temperature and especially volumetric wetness of snow and ice are the key factors in calculating brightness temperature of the water surface-lake ice-snow cover-atmosphere system. This is clearly demonstrated in Fig. 5 showing slight discrepancies between model results and satellite data in various years. These discrepancies are caused by divergence of actual parameters (snow and ice wetness, air, snow and ice temperature) from their averages.

\section{Conclusions}

Using the authors' model of thermal emission of multilayered non-isothermal media, an analysis of ice cover phenology phases of large freshwater bodies based on SMOS MIRAS data $(1.4 \mathrm{GHz})$ was performed by examples of lakes Baikal, Ladoga, GBL, GSL, and Huron. The employed frequency range (L-band) allowed highlighting the state of ice and snow at greater depths compared to frequency ranges of AMSR-E and AMSR2. The theoretical analysis showed that L-band thermal emission was received practically from the whole lake ice column during both cold winter and melt periods. This makes it possible to remotely sense processes in ice and snow cover even in the melt period. For the first time SMOS MIRAS data were used to assess the phenology phases of freshwater lakes. Previously AMSR-E and AMSR2 with higher operational frequencies had been used for the purpose in the melt period providing information only about the surface layer of lake ice. Our study not only replicated earlier results for AMSR-E and AMSR2 (see references in Introduction), but also complemented them with new findings due to greater radiation penetration depth at MIRAS frequency $(1.4 \mathrm{GHz})$.

Comparison of the satellite data (SMOS MIRAS) and modeling results revealed three distinct brightness temperature time regions at the freezing lakes that are associated with water surface clear of ice (TR1); complete ice cover (TR2); short-lasting abrupt rise in brightness temperature by 40-90 K marking the period of dramatic change in ice cover structure and intense deterioration and melt (TR3).

The revealed patterns of seasonal variations of brightness temperature and related lake ice phonological phases can be used to assess the hydrological regime of freezing inland water bodies (rivers, lakes, water reservoirs) based on satellite microwave radiometry data. The obtained results can be useful for setting the operating terms of winter crossings and roads on ice, as with the beginning of ice deterioration, these transportation routes across water bodies become insecure and cannot be used any more.

Data availability. In this work, we use SMOS data obtained under ESA project No. 4747 "Remote mapping of Siberian saline soils". The data are available at https://earth.esa.int/web/guest/-/ smos-level-1c-full-polarisation-land-sea (last access: 21 August 2018). Multi-year observational data on air and water temperature, wind speed, ice thickness, and thickness of snow on ice for the study lakes were taken from different sources listed in detail in Sect. 2.2. The results presented in this paper will be available soon at the website of the Department of Earth Studies from Space, Space Research Institute of the Russian Academy of Sciences (http://www.iki.rssi.ru/asp/, last access: 21 August 2018).

Author contributions. The present work was guided by ES. Model development and calculations were conducted by VT and ES. Acquisition, processing, and assimilation of the satellite data were performed by IK. AR analyzed the satellite data, as well as climatic, meteorological, and glaciological characteristics of the study lakes and regions. All authors took part in the discussions of the received results. The preparation of the manuscript was the responsibility of VT.

Competing interests. The authors declare that they have no conflict of interest.

Acknowledgements. The SMOS data used in this study were obtained under the European Space Agency Project No. 4747 "Remote mapping of Siberian saline soils". The work was supported by FASO Russia (Theme "Monitoring", State Register No. 01.20.0.2.00164). The study of snow cover and its influence on microwave radiation of freezing lakes was partially supported by the Russian Foundation for Basic Research (RFBR grants No. 18-05-00427, 18-05-00753). We thank Tatiana Yu. Bocharova for translating this paper.

Edited by: Lars Kaleschke

Reviewed by: two anonymous referees

\section{References}

Barry, R. G. and Gan, T. Y.: The Global Cryosphere. Past, Present, and Future, University Press, Cambridge, UK, 2011.

Bohren, C. F. and Huffman, D. R.: Absorption and Scattering of Light by Small Particles, Wiley-Interscience, New York, USA, 1983. 
Boyarskii, D. A. and Tikhonov, V. V.: The Influence of Stratigraphy on Microwave Radiation from Natural Snow Cover, J. Electromagnet. Wave., 14, 1265-1285, https://doi.org/10.1163/156939300X01201, 2000.

Boyarskii, D. A., Tikhonov, V. V., Kleeorin, N. I., and Mirovskii, V. G.: Inclusion of scattering losses in the models of the effective permittivity of dielectric mixtures and applications to wet snow, J. Electromagnet. Wave., 8, 1395-1410, 1994.

Boyarskii, D. A., Tikhonov, V. V., and Komarova, N. Yu.: Model of Dielectric Constant of Bound Water in Soil for Applications of Microwave Remote Sensing, Prog. Electromagn. Res., 35, 251269, https://doi.org/10.2528/PIER01042403, 2002.

Choudhury, B. J., Schmugge, T. J., Chang, A., and Newton, R. W.: Effect of Surface Roughness on the Microwave Emission From Soils, J. Geophys. Res., 84, 5699-5706, https://doi.org/10.1029/JC084iC09p05699, 1979.

Colbeck, S. C.: Snow metamorphism and classification, Seasonal Snowcovers: Physics, Chemistry, Hydrology, NATO ASI Series, 211, 1-35, 1987.

Cuffey, K. M. and Paterson, W. S. B.: The Physics of Glaciers, Elsevier, Burlington, 2010.

Dietz, A. J., Kuenzer, C., Gessner, U., and Dech, S.: Remote sensing of snow - a review of available methods, Int. J. Remote Sens., 33, 4094-4134, https://doi.org/10.1080/01431161.2011.640964, 2012.

Du, J., Kimball, J. S., Duguay, C., Kim, Y., and Watts, J. D.: Satellite microwave assessment of Northern Hemisphere lake ice phenology from 2002 to 2015, The Cryosphere, 11, 47-63, https://doi.org/10.5194/tc-11-47-2017, 2017.

Galakhov, V. L.: Remote sensing methods Ocean, Leningradskii politekhnicheskii institute, Leningrad, 1980 (in Russian).

Galaziya, G.: Baikal in questions and answers, Vostochno-Sibirskoe knizhnoe izdatel'stvo, Irkutsk, Russia, 1984 (in Russian).

Gray, D. M. and Male, D. H. (Eds): Handbook of Snow, Pergamon Press, Toronto, Canada, 1986.

Gunn, G. E., Duguay, C. R., Derksen, C., Lemmetyinen, J., and Toose, P.: Evaluation of the HUT modified snow emission model over lake ice using airborne passive microwave measurements, Remote Sens. Environ., 115, 233-244, https://doi.org/10.1016/j.rse.2010.09.001, 2011.

Gutierrez, A., Castro, R., and Vieira P.: SMOS L1 Processor L1c Data Processing Model, DEIMOS Engenharia, Lisboa, Portugal, available at: https://earth.esa.int/documents/10174/1854456/ SMOS_L1c-Data-Processing-Models (last access: 17 August 2018), 2014.

Heygster, G., Hendricks, S., Kaleschke, L., Maass, N., Mills, P., Stammer, D., Tonboe, R. T., and Haas, C.: L-Band Radiometry for Sea-Ice Applications, Final Report for ESA ESTEC Contract 21130/08/NL/EL, Institute of Environmental Physics, University of Bremen November 2009, available at: http://www.iup. uni-bremen.de/iuppage/psa/documents/smos_final.pdf (last access: 17 August 2018), 2009.

Huntemann, M., Heygster, G., Kaleschke, L., Krumpen, T., Mäkynen, M., and Drusch, M.: Empirical sea ice thickness retrieval during the freeze-up period from SMOS high incident angle observations, The Cryosphere, 8, 439-451, https://doi.org/10.5194/tc-8-439-2014, 2014.

Ishimaru, A.: Wave Propagation and Scattering in Random Media, Academic Press, New York, USA, 1978.
Kaleschke, L., Tian-Kunze, X., Maaß, N., Mäkynen, M., and Drusch, M.: Sea ice thickness retrieval from SMOS brightness temperatures during the Arctic freeze-up period, Geophys. Res. Lett., 39, L05501, https://doi.org/10.1029/2012GL050916, 2012.

Kaleschke, L., Tian-Kunze, X., Maaß, N., Beitsch, A., Wernecke, A., Miernecki, M., Müller, G., Fock, B. H., Gierisch, A. M. U., Schlünzen, K. H., Pohlmann, T., Dobrynin, M., Hendricks, S., Asseng, J., Gerdes, R., Jochmann, P., Reimer, N., Holfort, J., Melsheimer, C., Heygster, G., Spreen, G., Gerland, S., King, J., Skou, N., Søbjærg, S. S., Haas, C., Richter, F., and Casal, T.: SMOS sea ice product: Operational application and validation in the Barents Sea marginal ice zone, Remote Sens. Environ., 180, 264-273, https://doi.org/10.1016/j.rse.2016.03.009, 2016.

Kang, K.-K.: Passive Microwave Remote Sensing of Ice Cover on Large Northern Lakes: Great Bear Lake and Great Slave Lake, Northwest Territories, Canada, PhD thesis, University of Waterloo, Waterloo, Ontario, Canada, 148 pp., 2012.

Kang, K.-K., Duguay, C. R., Howell, S. E. L., Derksen, C. P., and Kelly, R. E. J.: Sensitivity of AMSR-E Brightness Temperatures to the Seasonal Evolution of Lake Ice Thickness, IEEE Geosci. Remote, 7, 751-755, https://doi.org/10.1109/LGRS.2010.2044742, 2010.

Kang, K.-K., Duguay, C. R., and Howell, S. E. L.: Estimating ice phenology on large northern lakes from AMSR-E: algorithm development and application to Great Bear Lake and Great Slave Lake, Canada, The Cryosphere, 6, 235-254, https://doi.org/10.5194/tc-6-235-2012, 2012.

Kang, K.-K., Duguay, C. R., Lemmetyinen, J., and Gel, Y.: Estimation of ice thickness on large northern lakes from AMSR-E brightness temperature measurements, Remote Sens. Environ., 150, 1-19, https://doi.org/10.1016/j.rse.2014.04.016, 2014.

Kerr, Y. H., Waldteufel, P., Wigneron, J.-P., Delwart, S., Cabot, F., Boutin, J., Escorihuela, M. J., Font, J., Reul, N., Gruhier, C., Juglea, S. E., Drinkwater, M. R., Hahne, A., Martin-Neira, M., and Mecklenburg, S.: The SMOS Mission: New Tool for Monitoring Key Elements of the Global Water Cycle, P. IEEE, 98, 666-687, https://doi.org/10.1109/JPROC.2010.2043032, 2010.

Kontu, A., Lemmetyinen, J., Pulliainen, J., Seppanen, J., and Hallikainen, M.: Observation and Modeling of the Microwave Brightness Temperature of Snow-Covered Frozen Lakes and Wetlands, IEEE T. Geosci. Remote, 52, 3275-3288, https://doi.org/10.1109/TGRS.2013.2272077, 2014.

Kotlyakov, V. V.: Selected works in six books, Book 1: Glaciology of Antarctica, Nauka, Moscow, 2000 (in Russian).

Kozlov, D. B.: Ice of freshwater reservoirs and streams, MGU, Moscow, 2000 (in Russian).

Kuz'min, P. P.: The physical properties of snow cover, Gidrometeoizdat, Leningrad, 1957 (in Russian).

Lemmetyinen, J.: Microwave radiometry of snow covered terrain and calibration of an interferometric radiometer, Doctoral dissertation, Aalto University publication series doctoral dissertations 142/201, School of Electrical Engineering, Department of Radio Science and Engineering, Helsinki, 162 pp., 2012.

Lemmetyinen, J., Pulliainen, J., Rees, A., Kontu, A., Qiu, Y., and Derksen, C.: Multiple-Layer Adaptation of HUT Snow Emission Model: Comparison With Experimental Data, IEEE T. Geosci. Remote, 48, 2781-2794, https://doi.org/10.1109/TGRS.2010.2041357, 2010. 
Maaß, N., Kaleschke, L., Tian-Kunze, X., and Drusch, M.: Snow thickness retrieval over thick Arctic sea ice using SMOS satellite data, The Cryosphere, 7, 1971-1989, https://doi.org/10.5194/tc7-1971-2013, 2013.

Macelloni, G., Brogioni, M., Pettinato, S., Zasso, R., Crepaz, A., Zaccaria, J., Padovan, B., and Drinkwater, M. R.: Ground-Based L-Band Emission Measurements at Dome-C Antarctica: The DOMEX-2 Experiment, IEEE T. Geosci. Remote, 51, 47184730, https://doi.org/10.1109/TGRS.2013.2277921, 2013.

Macelloni, G., Brogioni, M., Aksoy, M., Johnson, J. T., Jezek, K. C., and Drinkwater, M. R.: Understanding SMOS data in Antarctica, in: 2014 IEEE Geoscience and Remote Sensing Symposium (IGARSS), Quebec City, QC, Canada, 13-18 July 2014, IEEE, 3606-3609, https://doi.org/10.1109/IGARSS.2014.6947263, 2014.

Magand, O., Picard, G., Brucker, L., Fily, M., and Genthon, C.: Snow melting bias in microwave mapping of Antarctic snow accumulation, The Cryosphere, 2, 109-115, https://doi.org/10.5194/tc-2-109-2008, 2008.

Mätzler, C. and Wiesmann, A.: Extension of the Microwave Emission Model of Layered Snowpacks to CoarseGrained Snow, Remote Sens. Environ., 70, 317-325, https://doi.org/10.1016/S0034-4257(99)00047-4, 1999.

Naderpour, R., Schwank, M., and Mätzler, C.: Davos-Laret Remote Sensing Field Laboratory: 2016/2017 Winter Season L-Band Measurements Data-Processing and Analysis, Remote Sens., 9, 1185, https://doi.org/10.3390/rs9111185, 2017.

Rees, W. G.: Remote Sensing of Snow and Ice, Taylor \& Francis Group, New York, 2006.

Polder, D. and van Santen, J. H.: The effective permeability of mixtures of solids, Physica, 12, 257-271, https://doi.org/10.1016/S0031-8914(46)80066-1, 1946.

Pulliainen, J. T., Grandell, J., and Hallikainen, M. T.: HUT snow emission model and its applicability to snow water equivalent retrieval, IEEE T. Geosci. Remote, 37, 3, 1378-1390, https://doi.org/10.1109/36.763302, 1999.

Richter, F., Drusch, M., Kaleschke, L., Maßß, N., Tian-Kunze, X., and Mecklenburg, S.: Arctic sea ice signatures: Lband brightness temperature sensitivity comparison using two radiation transfer models, The Cryosphere, 12, 921-933, https://doi.org/10.5194/tc-12-921-2018, 2018.

Ricker, R., Hendricks, S., Kaleschke, L., Tian-Kunze, X., King, J., and Haas, C.: A weekly Arctic sea-ice thickness data record from merged CryoSat-2 and SMOS satellite data, The Cryosphere, 11, 1607-1623, https://doi.org/10.5194/tc-11-1607-2017, 2017.

Rouse, W. R., Blanken, P. D., Bussieres, N., Oswald, C. J., Schertzer, W. M., Spence, C., and Walker, A. E.: An Investigation of the Thermal and Energy Balance Regimes of Great Slave and Great Bear Lakes, J. Hydrometeorol., 9, 1318-1333, https://doi.org/10.1175/2008JHM977.1, 2008.

Rumyantsev, V. A. (Ed.): Lake Ladoga and the sights of its coast, Atlas, Nestor-Istoriya, St. Petersburg, Russia, 2015 (in Russian).

Rumyantsev, V. A., Drabkova, V. G., and Izmailova, A. V.: Great Lakes of the World, Lema, St. Petersburg, Russia, 2012 (in Russian).

Sahr, K., White, D., and Kimerling, A. J.: Geodesic Discrete Global Grid System, Cartogr. Geogr. Inf. Sc., 30, 121-134, 2003.
Sharkov, E. A.: Passive Microwave Remote Sensing of the Earth: Physical Foundations, Springer/PRAXIS, Berlin Heidelberg/UK, 2003.

Singh, V. P., Singh, P., and Haritashya, U. K. (Eds): Encyclopedia of Snow, Ice and Glaciers, Springer, Dordrecht, 2011.

Schwank, M. and Naderpour, R.: Snow Density and Ground Permittivity Retrieved from L-Band Radiometry: Melting Effects, Remote Sens., 10, 354, https://doi.org/10.3390/rs10020354, 2018a.

Schwank, M. and Naderpour, R.: Snow Wetness Retrieved from L-Band Radiometry, Remote Sens., 10, 359, https://doi.org/10.3390/rs10030359, 2018b.

Schwank, M., Rautiainen, K., Mätzler, C., Stähli, M., Lemmetyinen, J., Pulliainen, J., Vehviläinen, J., Kontu, A., Ikonen, J., Ménard, C. B., Drusch, M., Wiesmann, A., and Wegmüller, U.: Model for microwave emission of a snow-covered ground with focus on L band, Remote Sens. Environ., 154, 180-191, https://doi.org/10.1016/j.rse.2014.08.029, 2014.

Schwank, M., Mätzler, C., Wiesmann, A., Wegmüller, U., Pulliainen, J., Lemmetyinen, J., Rautiainen, K., Derksen, C., Toose, P., and Drusch, M.: Snow Density and Ground Permittivity Retrieved from L-Band Radiometry: A Synthetic Analysis, IEEE J. Sel. Top. Appl., 8, 1-14, https://doi.org/10.1109/JSTARS.2015.2422998, 2015.

Tedesco, M. (Ed.): Remote sensing of the cryosphere, JohnWiley \& Sons, Oxford, England, 2015.

Tian-Kunze, X., Kaleschke, L., Maaß, N., Mäkynen, M., Serra, N., Drusch, M., and Krumpen, T.: SMOS-derived thin sea ice thickness: algorithm baseline, product specifications and initial verification, The Cryosphere, 8, 997-1018, https://doi.org/10.5194/tc8-997-2014, 2014.

Tikhonov, V. V., Bojarskii, D. A., Kitaev, L. M., Raev, M. D., and Cherenkova, E. A.: Regional Features of Microwave Radiation and Snow Cover Interaction on the Example of the North of the European Part of Russia, in: 10th Specialist Meeting on Microwave Radiometry and Remote Sensing of Environment, Firenze, Italy, 11-14 March 2008, report 152, https://doi.org/10.1109/MICRAD.2008.4579512, 2008.

Tikhonov, V. V., Boyarskii, D. A., Repina, I. A., Raev, M. D., Sharkov, E. A., and Alexeeva, T. A.: Snow Cover Effect on Brightness Temperature of Arctic Ice Fields Based on SSM/I Data, in: Pr. Electromagn. Res. S., Stockholm, Sweden, 12-15 August 2013, 514-518, 2013.

Tikhonov, V. V., Boyarskii, D. A., Sharkov, E. A., Raev, M. D., Repina, I. A., Ivanov, V. V., Alexeeva, T. A., and Komarova, N. Yu.: Microwave Model of Radiation from the Multilayer "Ocean-atmosphere" System for Remote Sensing Studies of the Polar Regions, Prog. Electromagn. Res. B, 59, 123-133, https://doi.org/10.2528/PIERB14021706, 2014.

Tikhonov, V. V., Raev, M. D., Sharkov, E. A., Boyarskii, D. A., Repina, I. A., and Komarova, N. Yu.: Satellite Microwave Radiometry of Sea Ice of Polar Regions: a Review, Izv. Atmos. Ocean. Phy.t, 52, 1012-1030, https://doi.org/10.1134/S0001433816090267, 2016.

Tikhonov, V. V., Raev, M. D., Sharkov, E. A., Boyarskii, D. A., and Komarova, N. Yu.: A model of microwave emission of Antarctic snow-firn layers, Current Problems in Remote Sensing of the Earth from Space, 14, 200-204, https://doi.org/10.21046/20707401-2017-14-1-200-204, 2017 (in Russian). 
Tulokhonov, A. K. (Ed.): Baikal: nature and people. Encyclopedic Guide, Izdatel'skii dom EKOS, Ulan-Ude, Russia, 2008 (in Russian).

Voitkovskiy, K. F.: Fundamentals of glaciology, Nauka, Moscow, 1999 (in Russian).

Wiesmann, A. and Mätzler, C.: Microwave emission model of layered snowpacks, Remote Sens. Environ., 70, 307-316, https://doi.org/10.1016/S0034-4257(99)00046-2, 1999.

Woo, M.-K., Modeste, P., Martz, L., Blondin, J., Kochtubajda, B., Tutcho, D., Gyakum, J., Takazo, A., Spence, C., Tutcho, J., Cenzo, P., Kenny, G., Stone, J., Neyelle, I., Baptiste, G., Modeste, M., Kenny, B., and Modeste, W.: Science Meets Traditional Knowledge: Water and Climate in the Sahtu (Great Bear Lake) Region, Northwest Territories, Canada, ARCTIC, 60, 3746, 2007.
Zhou, L., Xu, S., Liu, J., and Wang, B.: On the retrieval of sea ice thickness and snow depth using concurrent laser altimetry and L-band remote sensing data, The Cryosphere, 12, 993-1012, https://doi.org/10.5194/tc-12-993-2018, 2018.

Zuerndorfer, B. W., England, A. W., Dobson, M. C., and Ulaby, F. T.: Mapping freeze/thaw boundaries with SMMR data, Agr. Forest Meteorol., 52, 199-225, https://doi.org/10.1016/01681923(90)90106-G, 1990.

Zwally, H. J. and Giovinetto, M. B.: Accumulation in Antarctica and Greenland derived from passive-microwave data: a comparison with contoured compilations, Ann. Glaciol., 21, 123-130, https://doi.org/10.1017/S0260305500015706, 1995. 